\title{
Marx's Social Development Theory and Its Contemporary Enlightenment
}

\author{
Xiaorong $\mathrm{Mi}^{1} \&$ Houjun $\mathrm{Mao}^{1}$ \\ ${ }^{1}$ Institute of Marxism, Southwest University, Chongqing, China \\ Correspondence: Xiaorong Mi, Institute of Marxism, Southwest University, Chongqing 400715, China. E-mail: \\ mxr1713@163.com
}

Received: January 7, 2013 Accepted: February 19, 2013 Online Published: March 22, 2013

doi:10.5539/ach.v5n2p73

URL: http://dx.doi.org/10.5539/ach.v5n2p73

\begin{abstract}
Marx's social development theory is the major content of Marx's social and historical philosophy and is an important scientific achievement in his arduous exploration. Today, when social development encounters contradictions and difficulties, we may review Marx's social development theory with an expectation to seek for enlightenment to resolve contradictions and difficulties in contemporary social development.
\end{abstract}

Keywords: Marx, social development theory, contemporary enlightenment

Social development theory is a major domain of discourse and main content in Marx's social and historical philosophy. The lifelong theoretical works of Marx are mainly dedicated to study of the social and history field and abundant resources of thinking about social development are implied in the theoretical system. Although these resources of thinking may not resolve all contradictions and all specific problems in contemporary social development, the basic standpoint, viewpoint and method in Marx's social development theory are still a coordinate for us to explore contemporary social development theory and practice.

\section{Theory on Alienation and Humanistic Development View Are the Exploration Achievements of Marx in His Early Social Development Theory}

Resources of thinking in Marx's social development theory are implied in his series of works, such as, "Economics Philosophy Manuscript in 1844", "The Outline of Feuerbach", "German Ideology", "The Philosophy of Poverty", "The Communist Manifesto", "The Civil War in France", "Critique of the Gotha Program", and "Capital", which went through a process from preliminary exploration to mature construction.

In his early works "Economics Philosophy Manuscript in 1844", Marx made a thorough investigation and exploration in contradictions and difficulties in modern social development and proposed his early social development theory based on alienated labor theory. The basic idea is as following:

Firstly, Marx treated social development conditions on the standpoint of the proletariat and judged that there existed serious problems in contemporary social development by consideration of the extremely serious tribulation of the proletariat. During the decline period of social economy, poverty of workers was more and more aggravated; during the growth period of social economy, poverty of workers had an intricate form and potential characteristics; during the peak period of social economy, poverty of workers became more prominent and began to be amplified.

Secondly, Marx's philosophical vision surpassing British classical economics gave a profound portrayal of alienation under the capitalism. "The more wealth a worker produces, the greater the power and quantity of his products and the more impoverished he is. The more commodities a worker produces, the more possible he becomes a cheap commodity. Appreciation of the world of material is proportional to depreciation of the world of people." (Note 1) "The more a worker produces, the less he consumes; the more wealth he creates, the less value he is and the more humble he is; the more flawless the products of a worker, the more deformed he is; the more civilized the products a worker produces, the more savage he is; the more powerful the labor, the more incapable a worker; the more ingenious the labor, the more foolish a worker and the more possible it is that he becomes a slave of the nature." (Note 2) Marx portrayed the miserable life of workers occupying an overwhelming majority of population in the process of capitalism social development with the above profound and vivid utterances and generalized several basic contradictions and problems in the social development under 
the capitalism condition: alienation of laborers and labor products; alienation of laborers and labor; alienation of human beings and their species; alienation of human and human.

Thirdly, Marx abandoned private property and made a tentative exploration in the way out for social development in the future. Marx made a humanistic analysis in private property in his "Economics Philosophy Manuscript in 1844", revealed profoundly the non-human nature of private property and pointed out that the ultimate approach to eliminate labor alienation and realize the comprehensive development and free liberation of human was implied in the communism action of abandoning private property and eliminating private ownership.

From the perspective of development theory, the early explorations of Marx in social development theory not only had its historical progress, but also had its limitations. On one hand, he criticized the humanistic value of the capitalism society with this alienation theory and obtained the theoretical conclusion of communism revolution; yet, on the other hand, Marx's analysis still failed to thoroughly separate from the set pattern of humanism and failed to form his scientific philosophical thinking mode and the social development theory based on historical materialism.

\section{Maturity of Marx's Social Development Theory: Practical Materialism}

Marx's systematic and scientific social development theory was gradually realized in his works, such as, "The Outline of Feuerbach", "German Ideology", "The Philosophy of Poverty", "The Communist Manifesto", "The Civil War in France", "Critique of the Gotha Program", and "Capital".

Marx's social development theory system is constituted by a series of basic categories, principles, propositions and basic methods. This theoretical system achievement embodies transfer of Marx's philosophical thinking paradigm and transformation of his social development view.

"The philosophers merely explain the world in different ways, and the problem lies in how to change the world." (Note 3) Marx was established in practicing the methodology and finally found a realistic approach to correctly explain the world and to effectively change the world. Change in the practical thinking mode of Marx's social development theory reflected in his several important works, such as, "Economics Philosophy Manuscript in 1844 " which finished his thorough criticism on the whole western philosophy at a height of philosophical paradigm; "The Outline of Feuerbach" which studied and expounded social development issues from practical philosophical paradigm; "German Ideology" which systematically expressed his social development theory of practical materialism.

"In essence, all social life is practical. Anything mysterious that leads a theory into mysticism can be resolved in a rational way in human's practice and their understanding in the practice." (Note 4) "People produce certain and necessary relations independent of their will in the social production of their own life, namely, production relations suitable with a certain development stage of their material productivity. The sum of these production relations constitute the economic structure of the society, namely, the realistic foundation with legal and political superstructure set upright which is suitable with certain social form of consciousness. The production means of material life restrains the entire process of social life, political life and spiritual life. It is not that people's consciousness determines their existence. On the contrary, it is people's social existence that determines people's consciousness." (Note 5)

The above statements in works of Marx expounded his basic idea of social development theory and embodied the revolution of the philosophical paradigm in Marx's social development theory. Its epoch-making significance was that he made a fundamental transfer in the philosophical theme, concentrated the focus of attention on the human world and paid attention to the realistic human and their development. Hence, in order to explore the internal logic and basic law in human world development, Marx firstly searched for the fundamental proof to understand, explain and grasp human world and this fundamental proof was human practical activity as practice was the fundamental basis of human existence and development and was a dynamic, continuously generated and developed noumenon of the whole human world. Outside practice, there was neither social life nor social development.

\section{The Basic Content of Marx's Social Development Theory}

The content of thinking in Marx's social development theory system was extremely abundant and the problems involved are quite extensive, not only including principle study in a general vision, but also including specific study from a particular perspective. Thus, the basic content framework of Marx's social development theory mainly contains two major constituting parts, one general theory about social development and the other specific theory about social development.

The first one is the general theory about social development. This theory is mainly a social development theory 
in the sense of historical materialism. This theory mainly expounds the general viewpoint, proposition and principle of social development. Its main content contains precondition and basis of social history, the subjective and objective relations of social development, basic contradictions and rules of social development, basic motive system of social development, classification and evolution of social formation and relation between social development and human being, etc. All these basic principles and general theories are of strong truth and are scientific establishment of social and historical view and historical analysis method. They have a guiding significance of world outlook and methodology to rationally know about social development and correctly take part in social practice.

The other one is the specific theory about social development. This theory is a social development theory proposed by regarding a particular society as the target. A lot of Marx's works typically focused on and profoundly and meticulously studied particular social targets, so two major research theories specially about these two aspects of particular targets were formed, one research theory about the problem of modern capitalism social development and the other research theory about the problem of non-western social development, such as, origin, development and tendency in the future of their social pattern and such problems as social development condition, environment, approach and mechanism of these particular targets. This part of theory was deepening and development of the general theory about social development and successful dissection of modern capitalism society as well as beneficial exploration of social development of non-western countries. All these specific theories about social development have strong realistic guidance significance in the contemporary world, especially in the large number of developing countries in the contemporary world.

\section{The Contemporary Enlightenment of Marx's Social Development Theory}

Development is not only a theme of the times, but also an eternal subject of human kind. In essence, this subject is, first of all, a practical issue, and, in the meantime, an issue of cognition. In any times, practice of development clamors for a theory matched with the times. It should be acknowledged that ever since Marx passed away, capitalism social development went through free competition, private monopoly and national monopoly and so far, it has developed to a stage of international monopoly and indeed, great changes have taken place in the global situation. Nevertheless, all these changes reflect nothing but change in the specific pattern of capitalism instead of change in its essence. So long as the nature of the times has not taken any fundamental change, Marx's social development theory that is used directly to analyze the times still has its certain contemporary value. The hot sale of "Capital" once again by Marx during the global financial crisis in 2008 was a vigorous proof.

Beneficial enlightenment of Marx's social development theory to the contemporary social development mainly has the following two aspects.

In the first place, Marx's social development theory treats and analyzes contemporary social development in a scientific and rational attitude. In the eyes of Marx, human society was an organic system, so promoting and reforming human social development had to take practice as the approach and follow the objective law of the social system. The organism of human society has its particular element, structure, mechanism and function. In addition, the social system is open and exchanges material, energy and information with the environment. Although the subject of designing and reforming the society is man with a purpose and consciousness, they have to regard the social system as objective existence when they play their role as the historical subject and follow the social objective law to design and promote development of the society. That is to say, man should realize their purpose on the basis of conforming to the social objective principle and law.

In the second place, Marx's social development theory enlightens us to make profound introspection on selection of the value goal of contemporary social development. Man is not a means and instrument of social development, and the highest value and ultimate value of social development is development of man. A review on Marx's realistic criticism on labor alienation and his theory about construction of the ideal goal of free and comprehensive development of social man in the future, it is found that the value core of Marx's social development theory is man. However, ever since the period of industrialization until today, the development condition of the world, all without exception, indicates that the value goal of human social development has been seriously biased and the phenomenon of alienation of man has not only been buried in the grave together with Marx, but has been more deteriorated. Therefore, it is necessary for us to calm down and introspect and return to the value. Only in this way, is it possible for the social development to really unify conformation to the goal and conformation to the law.

When we review Marx's theories today, we should not ignore the historical caution proposed by the vast majority of great masters represented by Marx. Only if we establish a rational social development value goal and select a scientific and correct social development path, can we impel human society to step forward towards a 
free and harmonious direction in which man is kind and shares richness together.

\section{References}

Bao, Z. (1999, March). Introduction to Contemporary Social Development. East China Normal University Press.

Feng, Z. (2010, January). Towards Realistic Social and Historical Philosophy: Contemporary Value of Marx's Social and Historical Theory. Wuhan University Press.

He, L. (2002, May). Transition between Marx's Philosophy and "Existential Theory" Paradigm. Social Sciences in China.

Marx Karl Heinrich \& Engels Friedrich. (1995). Karl Marx and Frederick Engels (Vol. 1). Beijing: People's Publishing House.

Marx Karl Heinrich \& Engels Friedrich. (2002). Karl Marx and Frederick Engels (Vol. 3). Beijing: People's Publishing House.

Yang, X., \& Feng, Z. (2002, October). Marx's “World History” Theory and Globalization. People's Publishing House.

Zhang, Z., \& Ma, F. (2001, January). Developmental Sociology. China Social Sciences Publishing House.

\section{Notes}

Note 1. Karl Marx and Frederick Engels, Volume 3. Beijing: People's Publishing House, 2002, p.267.

Note 2. Karl Marx and Frederick Engels, Volume 3. Beijing: People's Publishing House, 2002, p.269.

Note 3. Karl Marx and Frederick Engels, Volume 1. Beijing: People's Publishing House, 1995, p.56.

Note 4. ibid.

Note 5. Karl Marx and Frederick Engels, Volume 2. Beijing: People's Publishing House, 1995, p.32. 